\title{
THE BRITISH JOURNAL OF PSYCHIATRY
}

August 1987

Volume 151

Papers

The symploms of chronic schizophrenia: a re-examination of the positive-negative dichotony. $P, F$. Liddle

The efficacy of electroconvulsive therapy in the treatment of schizophrenia: a comparative study. K. R. Atruham and P. Ku/hara

Expressed emotion and schizophrenia in North India

I. Cross-cultural transfer of ratings of relatives expressed emotion. N. N. Wig, D. K. Menon, H. Bedi, A. Ghosh L. Kuipers. J. Leff. A. Korren, R. Day, N. Sartoriw, G. Ermberg and A. Jahlensk

I1. Disiribution of expressed emotion components among relatives of schizophrenic patients in Aarhus and Chandigarh. N. N. Wig. D. K. Menon. H. Bedi. J. Leff. L. Kuipers, A. Ghosh. R. Day. A. Karten, G. Enberg, N. Sartorius and A. Jablensky

III. Inluence of relatives" expressed emotion on the course of schizophrenia in Chandigarh. J. Leff. A. N. Wig, A. Ghosh, H Bedi, D. K. Menon, L Kuipers, A. Korten, G. Emberg, R. Day, N. Sarrorius and A. Jabiknk y

Expressed emotion in individual and family settings: a comparative study. $G$. $I$, Szmukler. R. Berkonit: I. Eikler, J. Leff and C. Dare

The impact of recent undesirable life events on psychiatric disorders in childhood and adolescence. I. M. Goodyer, 1. Kolvin and S. Gaizanis

Brief psychotherapy in the treatment of anorexia nervosa: outcome at one year. A. Holl and A. H. Crisp

Anorexia nervosi: an object relations approach to primary treatment. $M$. Home and $\boldsymbol{M}$. Gallen

Hereditary agoraphobia and obsessive-compulsive behaviour in relatives of patients with Gilles de la Tourette's syndrome. D. E. Comings and B. G. Comings

Depressed mood after stroke: a community study of its frequency. D. T. Wade, J. Legh-Smith and R. A. Hewer

Correlation between the 37-item mental test scare and abbreviated 10-item mental test score by psychogeriatric day patients. $P$. Thompson ard $G$. Ble.ssed

Monoumine oxidase inhibitors and narcotic analgesics: a critical review of the implications for treatment. B. Broune and S. Linter

Clomipramine. 1ryptophan and lithium in combination for resistant endogenous depression: seven case studies, A. S. Halle, A. W. Proctor and P. K. Bridges

Sticide in Scottish prisons. $S$. A. Backett

Reality onemation and reminiscence therapy: a controlled cross-over study of elderly confused people. S. Baines. P. Saxby and K. Ehlert

Explotations of a crisis intervention service. D. A. Winter. H. Shivakumar, R. J. Brown, M. Roin, W. I. Drysdale and S. Jones

Referrals to a Scottish drug dependence unit: a descriptive study. $M . M$. O'Rowke and J. A. Tartor

Comparison of electrical measurements on constant voltage and constant current ECT machines. R. Railton, J. Fisher, A. Sinvlair and J. M. Shrigmankar

Brief Reports

Varicties of combat stress reaction: an immsnological metaphor. $R$. Garb, I. Kutz, A, Bleich and 7. Solontom

Meroin abusers in psychiatric beds: a Glasgow study. A. A. Fraser. A. Greer and P. Jauhar

Capgras sythdrome: a case report from Zimbabwe. S. Chawa, T. Buchan and N. Golen

Ganser synctrome: a case report and discussion. P. D. Dabholkar

Folie a deux it bown's syndrome: a case report. C. J. Meakin, E. B. Renvoize and J. Kent

Psychiatric presentation of Creutzfeldt-Jakob disease: a case report. M.S. Keshovan, W. A. Lishman and J. T. Hughes

Capgras syndrome an unusual case and discussion of psychodynamic factors. R. $O$ Reilly and L. Mathorta

Correspondence 